\title{
DESALINATION, A STRATEGIC AND CONTROVERSIAL RESOURCE IN SPAIN
}

\author{
ANA ARAHUETES \& RUBÉN VILLAR \\ University of Alicante, Spain
}

\begin{abstract}
The need to find new sources of water due to the climatic conditions of certain areas of Spain, as well as the increasing urban tourism and agricultural demands, and in addition to the foreseen scenarios as a result of climate change, have led to the use of non-conventional resources, such as desalination. Although the Canary Islands already resorted to desalination plants 40 years ago, it was not until the 1990s that some of these plants began to be introduced to areas of high water deficit within the peninsula of Spain. Nevertheless, their boom occurred in 2005 due to the government's propulsion of the 'A.G.U.A.' program, through which they installed a multitude of plants along the Mediterranean coast, as a result of a change in government and in its water management policy. This source was seen as an almost inexhaustible and suitable alternative in comparison with transfers, because of their regional and political controversies. The water generation capacity of these new plants was calculated based on demand perspectives related to the real estate boom, with demand in volumes that were never reached, due to the bursting of the real estate bubble and the economic crisis. In addition, the high-energy consumption associated with the desalination process (reverse osmosis) substantially increases the price of water, which makes it impossible for some sectors, especially irrigators, to have access to these waters. This communication details all the aspects related to the evolution of desalination in Spain, as well as its current situation, where as a consequence of the above, these plants, which entailed a significant economic investment, are working at very low yields and using their water as a strategic resource, especially during times of drought.
\end{abstract}

Keywords: arid, cost, desalination, drought, energy use, potable water, resources, Spain, water

\section{INTRODUCTION}

The need to find new sources of supply, as a result of high demand or difficulty acquiring resources in some areas, led to the expansion and integration of non-conventional water sources such as reuse and desalination. In this paper, the case of desalination and its influence will be analyzed for Spain. Swyngedouw [1] considers desalination as the most recent mutation of the old hydraulic paradigm, noting that it has expanded massively throughout the world. This phenomenon was already observed in the natural hydrological cycle of water, where about $502,800 \mathrm{~km}^{3}$ of ocean water evaporates annually, plus about $65,200 \mathrm{~km}^{3}$ of continental water [2]. This process takes place in the desalination plants, an industrial infrastructure where the saline water is separated into two distinct flows; one with a low concentration of dissolved salts (the product water), and the other containing the rest of the dissolved salts (concentrate, rejection or brine). All this requires the use of energy in order to occur. According to what desalination technique is used, the energy expenditure may vary [3]. Water resources that are susceptible to being desalinated may have two main origins: seawater or saline, or brackish groundwater from either coastal aquifers that are in contact with the sea or aquifers that are isolated from the sea [4].

The increase in demand for fresh water has been one of the triggers that has forced countries in the world, especially in arid regions, to embark on ambitious plans to adopt and implement policies to achieve self-sufficiency in the production of water [5]. In the Middle East, a region of marked aridity, are currently located more than $50 \%$ of the seawater desalination plants in the world, especially in the Persian Gulf [6]. In Spain, desalination 
has emerged as the solution to all water problems, where dams or transfers have not been able to manage, due to scarcity, drought, social conflicts, environmental impact or interprovincial political disputes [7]. This country is an international reference in the field of desalination, both for the number of plants built and for the export of knowledge of technological advances, plant construction and exploitation [8].

As happened in the rest of the world, the first desalination plants that were built in Spain were thermal, with the use of plants based on membrane systems gradually increasing as technological advances made it possible to reduce the costs associated with the reverse osmosis process [9]. The desalination industry with the brand 'Spain' stands out, due to the meteoric process of internationalization developed during the last years. This promotion in the construction of highly efficient desalination plants is due to environmental requirements and high energy costs, which are crucial for development. In addition, the existing water imbalances in Spain justify this local development of desalination [8].

Desalination has the great advantage of feeding from an almost inexhaustible source, such as the sea, and not being subject to climatic variations; but also it presents a number of drawbacks that must be taken into account [10]-[12]:

- High energy consumption associated with its production $\left(3.7-4.3 \mathrm{kWh} / \mathrm{m}^{3}\right)$.

- Emission levels of greenhouse gases higher than those recommended by climate change policies.

- Degrading effects on the marine ecosystems.

- High concentrations of boron that can cause phytoxicity problems in certain crops (a problem solved in newly constructed plants).

- Imbalances and deficiencies in their composition, a consequence of their minimum calcium, deficiencies in sulfate and magnesium contents that make them need later remineralization.

- High acidity and corrosive power, which can cause problems in the pipes.

- Cost of water production is very high: it can range between 0.60 and $0.80 € / \mathrm{m}^{3}$.

Most of these problems can be mitigated by mixing this water with others in a proportion of desalinated water not exceeding 30-35\%. But a problem remains in the price: in this context, the importance of the water and energy nexus is clear [13] and especially significant in the process of desalination, due to the high energy consumption that this process entails. The average cost per unit of water in Spain requires $0.45 \mathrm{kWh} / \mathrm{m}^{3}$ [14], while reverse osmosis requires between $3.5 \mathrm{kWh} / \mathrm{m}^{3}$ (ideal conditions) and $5 \mathrm{kWh} / \mathrm{m}^{3}$ (even more in ancient plants) [15].

While technologies have been advancing for the process of decreasing energy expenditure, it is still not enough to talk about desalination as a major source of water. In addition, Spain suffers from a high degree of dependence on energy imports, concentrated mainly in imports from non-democratic countries and countries that are unstable in their energy policies, such as some of the Organization of Petroleum Exporting Countries (OPEC) members like Saudi Arabia, Libya, Nigeria, Iran, Iraq, and Algeria; this makes the process of obtaining water partially conditioned by external factors.

Nowadays, in the Iberian Peninsula, this virtually inexhaustible source of water that is independent of climatic conditions is only used as a complementary resource, due to the high economic cost involved. A good example of this high price is observed in the province of Alicante, where the cost of the desalinated water is almost five times what they pay for water from the Tajo-Segura transfer [16]. This cost makes its use inaccessible to some sectors, like agriculture, destining this new resource mainly for urban supply. 
With the entry into the Spanish government of the socialist party, in 2004, there was a reorientation of the water policies. After the repeal of the Ebro transfer, the new government promoted the 'A.G.U.A.' program, which contemplated the construction of a large number of desalination plants along the Mediterranean Arc that would cover future estimated demands and existing demands which were not yet fully met. The use of desalinated water brings new challenges to the professionals of the sector, who need a response to improve the viability of their use by an increase in the plant's energy efficiency, to minimize the environmental impacts that these plants generate, or to achieve a reduction of the price of desalinated water in order to make it more competitive and without the need for subsidies [17]. In this article, we will analyze the situation in Spain, from its beginnings to its current state, within the desalination industry.

\section{PAST AND PRESENT OF DESALINATION IN SPAIN}

A series of conjunctive factors, such as the geographical and climatological location in Spain, have favored the development of desalination as a technological option. In the first place, the existence of two archipelagos where tourism has a significant weight generated, from an early date, solvent demands for desalinated water on a scale that does not exist in any other developed country: and without alternative resources to be used to cover these demands [18]. Secondly, the remarkable hydraulic tradition of the country favored the transfer of technological knowledge for the development of the new sector. Finally, the recurrent cycles of droughts affect both the islands and the peninsula.

The first desalination plant (via MSF, flash distillation) was installed in Spain on Lanzarote Island in 1965 [19], followed by other plants in Ceuta, Fuerteventura and Las Palmas (Table 1). Some of these plants are already dismantled or conveniently retrofitted to new technologies [6], because the dominant technology at that time, now obsolete, was evaporation with MSF (multistage flash distillation) units [20].

Once this first stage was overcome, there was stagnation in the development of desalination plants as a consequence of the oil crisis, which forced new research aimed at saving the already installed plants. In this way, the evaporative process exchangers, which had a larger area of exchange, allowed for greater distillation without increasing energy consumption [20]. The decade of the 1980s is marked by the appearance of reverse osmosis and implantation of its membranes and processes. To date, reverse osmosis membranes have only been used to filter brackish water, where electro-dialysis was a perfectly viable technology. By this time, it should be emphasized that there were many private tourist complexes that had installed small units of mechanical compression of steam $(\mathrm{CV})$ to solve their supply problems. After the 90s, reverse osmosis takes over the desalination landscape in Spain. Although the Spanish electricity supply has been able to cope with

Table 1: First desalination plants in Spain [21].

\begin{tabular}{|c|c|c|c|}
\hline Name & Year & Capacity $\left.\mathbf{~ ( m}^{\mathbf{3}} / \mathbf{d a y}\right)$ & Process \\
\hline Termolariza* $\left(\right.$ Lanzarote) $^{*}$ & 1965 & 2.000 & MSF \\
\hline Ceuta I* $^{*}$ & 1969 & 4.000 & MSF \\
\hline Fuerteventura I* & 1970 & 2.000 & MSF \\
\hline Las Palmas I & 1979 & 20.000 & MSF \\
\hline
\end{tabular}

*Not currently operating. 
the consumption generated by these facilities, it is true that it has been helped by the contemporary coincidence of the appearance of energy recovery systems. These systems are responsible for considerably reducing electricity consumption, and are a technology in which Spain is a leading country.

Another determining factor in the hegemony of reverse osmosis has been the liberation of electric energy prices in the country, only now accessible to large consumers; the only exception being electrodialysis for desalination of brackish water or the reuse of urban waste water [6]. Since then, technological improvements have been decisive for the expansion of this practice in the country, making it more accessible to sectors that years ago could not even consider resorting to it. One of the triggers of this change has been the use of reverse osmosis, as opposed to distillation, because its technology is less dependent than the previous one on energy resources [19]. This is why, since the 1990s, Spain has invested in researching, both at public and private levels, any possible way of reducing energy consumption [22].

Desalination has continuously evolved in Spain, mainly due to the serious imbalance between water resources (motivated by the irregular rainfall of our geography) and the high consumption of certain areas, with intensive irrigated agriculture and tourism infrastructure, which consume specifically at our lower precipitation times. This justifies the installation of desalination plants [20]; however, its location is mainly reduced to the Mediterranean area (Catalonia, Valencian community, Murcia and Andalusia), as well as to the two archipelagos (Canary and Balearic Islands) and to cities located in North Africa (Ceuta and Melilla). In fact, at present, almost all the water consumed in Fuerteventura and Lanzarote is desalinated [23].

Thanks to the current facilities, Spain has increased its capacity to desalinate water during the last decade by more than three times, from $300,000 \mathrm{~m}^{3} /$ day in 1990 , to 1 million $\mathrm{m}^{3} /$ day in 2000 , and almost reaching 3 million $\mathrm{m}^{3} /$ day in the present. There are 50 plants, located between the Mediterranean Arc (especially the Valencian and Murcian regions) and the Canary Islands [24], that are responsible for producing more than $80 \%$ of this capacity, where the significant distribution is as follows: Valencia and Andalusia 25\%, Canary Islands $15 \%$, and the region of Murcia 20\%. These data place Spain as the fourth country in the world to be able to produce desalinated water [17].

Yet the problem of disuse still exists, since 2013 many plants have operated at very low production capacities, some plants are unfinished and others have not even begun to be built. Although thanks to this over-built capacity, supply is guaranteed in the face of future drought, and the fact that much of this water comes from desalination plants creates a new concept of relative scarcity. The demands of the urban tourism sector of the Spanish Mediterranean are covered with desalinated water, but there is still water scarcity for the agricultural sector [7].

\section{THE A.G.U.A. PROGRAM AND ITS CONSEQUENCES}

A notable milestone in the evolution of desalination in Spain, mainly at the quantitative level, was the creation of the Actions for the Management and Use of Water (A.G.U.A., or water, in Spanish) Program. This program came about with the return of the Socialist Party government in Spain, after the repeal of the Ebro transfer by Royal Decree 2/2004 and the promulgation of Law 11/2005, amending the National Hydrological Plan. These changes were intended to reorient water policy to meet new needs in the Mediterranean, by means 
of desalination [25]. The A.G.U.A. Program contemplated a series of actions, aimed at:

- Increasing the availability of water resources (by construction of desalination plants);

- Improving water resource management (by reuse of wastewater with tertiary systems, modernization of traditional irrigation systems, and improvement of large infrastructures and pipelines);

- Improvement of water quality, flood prevention and environmental restoration (by water treatment and pipelines).

In the first instance in the field of desalination, the proposed actions were intended to provide $650 \mathrm{hm}^{3}$ through the construction of 26 new desalination plants (Fig. 1) [26], although at present only 17 new desalination plants have been built. With a production capacity that reaches almost $350 \mathrm{hm}^{3}$, of which $155 \mathrm{hm}^{3}$ is destined to satisfy irrigation water needs of the peninsular southeast, the Spanish government obtained an agreement with the European Commission for the construction of these plants, claiming that it was an environmental investment. Up to $80 \%$ of the investment was received from European Cohesion Funds [18].

\section{WATER-ENERGY NEXUS IN DESALINATION}

An important aspect of the desalination processes is the water-energy nexus and its repercussions, in this case economic. The main problem of desalination, as mentioned, is the high energy expenditure required by this process, occurring mainly during the reverse osmosis phase. This expense is generated mainly by the high-pressure pumps that feed the frames and those that expel rejected water. Table 2 shows the energy consumption for a week, of the type that normally occurs during the different phases of desalination. These are two processes where the actions to be implemented when investing in new technologies have been focused, among which energy recovery stands out [16].

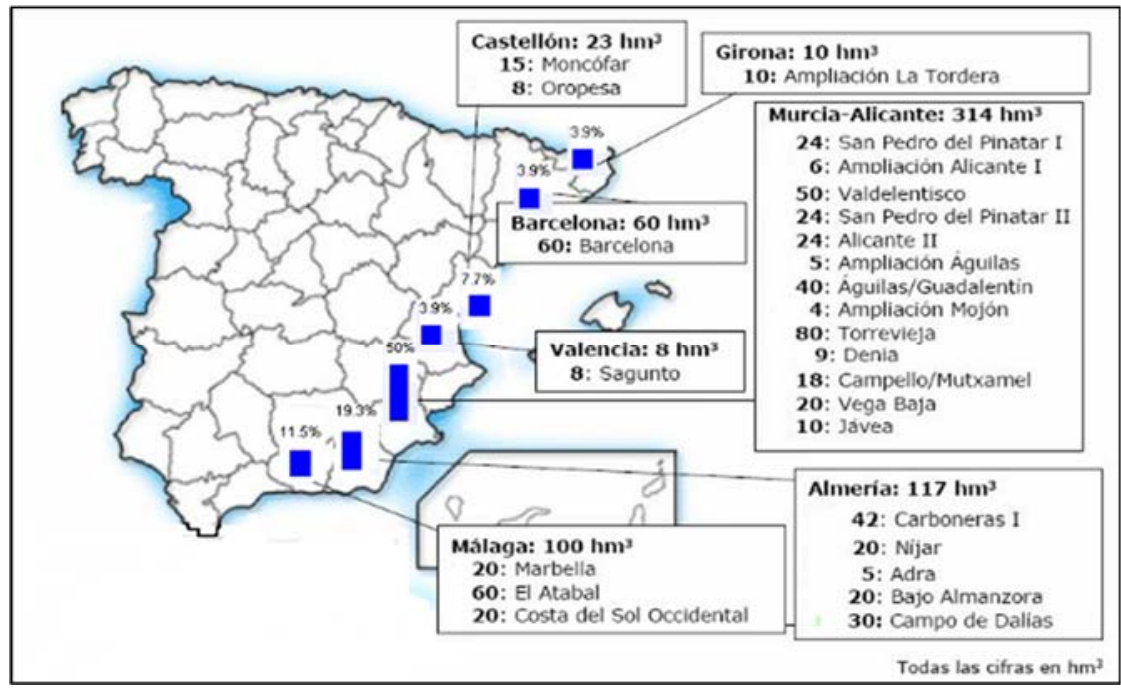

Figure 1: Desalination plants in the Mediterranean basins [3]. 
Table 2: Energy consumption for the different phases of the process (an example).

\begin{tabular}{|l|c|}
\hline \multicolumn{1}{|c|}{ Phase } & kWh \\
\hline Pump from the beach & 196,455 \\
\hline Pump filtered water & 128,143 \\
\hline Turbopump feed (TBBAS) & $1,247,393$ \\
\hline Pump of the resulting water & 234,636 \\
\hline Brine & $1,247,393$ \\
\hline Total process & $1,858,943$ \\
\hline
\end{tabular}

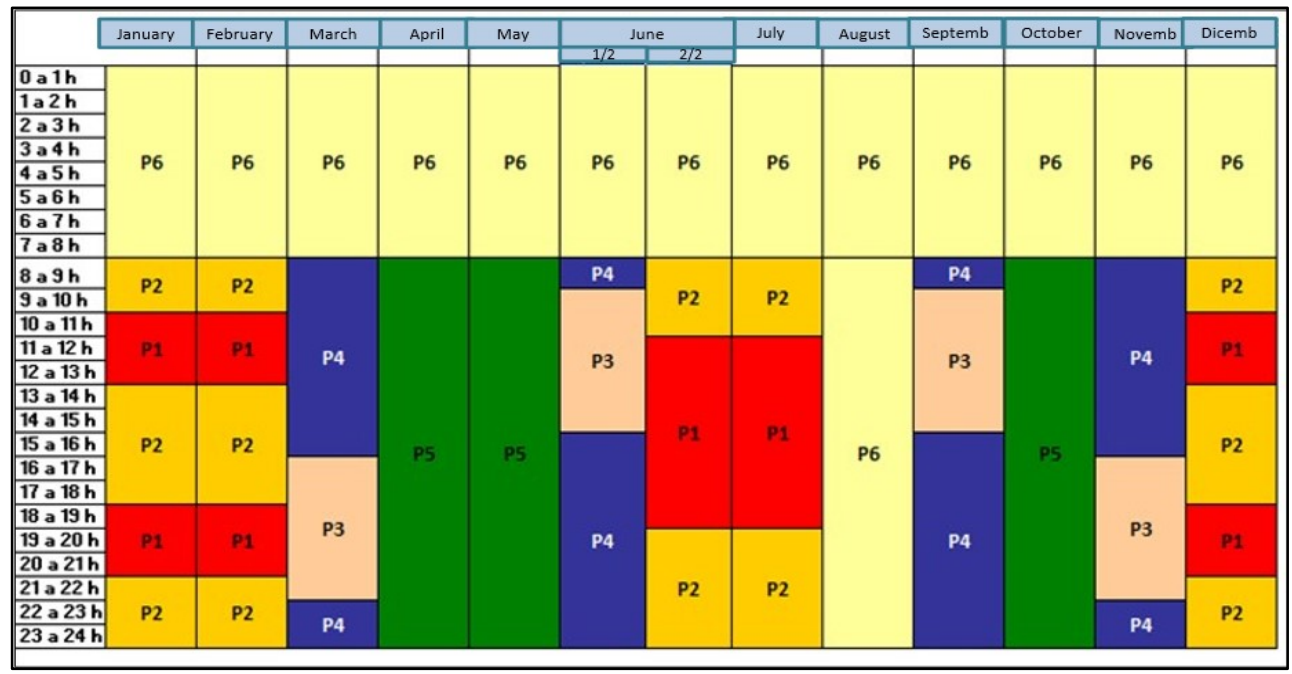

Figure 2: Tariff bands [16].

Table 3: Prices in 2014, according to consumption bands [16].

\begin{tabular}{|c|c|c|c|c|c|c|}
\hline Prices (€/MWh) & P1 & P2 & P3 & P4 & P5 & P6 \\
\hline $\begin{array}{c}\text { SSCC with ATR } \\
\text { (without I.E.) } \\
\text { (€/MWh) }\end{array}$ & 52.279 & 36.645 & 27.695 & 19.161 & 18.078 & 11.630 \\
\hline $\begin{array}{c}\text { TP (without I.E.) } \\
\text { (€/kW/year) }\end{array}$ & 39.139 & 19.587 & 14.334 & 14.334 & 14.334 & 6.540 \\
\hline
\end{tabular}

ATR: Procedures related to contracts (withdrawals, changes, withdrawals)

I.E .: Electricity tax

SSCC: Complementary Services

TP: Terms of power, function of contracted electrical power 
In addition to technological innovations, the use of low-cost tariff bands (depending on time of use and dates) also occurs. Fig. 2 shows these different tariff bands. Note that the P6 band, in addition to being applied at the times indicated in the figure, is also used during weekends and national holidays. An example of the use of the cheapest tariff bands is observed in the desalination 'Canal de Alicante 1', which is currently only in operation on weekends, taking advantage of the lower tariff, P6. Each tariff band corresponds to an amount from which the price to be paid is calculated. Table 3 shows the prices that Iberdrola established in 2014.

The cost of desalinated water is often masked between subsidies and benefits crossed with other products, especially with energy. A partial cost distribution of a plant can be obtained, corresponding to: $42 \%$ for depreciation; $45 \%$ for energy; and $13 \%$ for personnel, chemicals and others. The price of desalinated water is undoubtedly the highest price at which water can be purchased today. In comparison with conventional regulation and conduction methods or with groundwater, it is always unfavorable for desalination. That said, it should also be noted that the cost of desalinated water has been and will continue to be declining, while that of other conventional resources has been and will continue to be increasing [27].

In order to reduce energy consumption, technological advances have been made, such as the incorporation of energy recovery systems, or of new and more efficient membranes that can recover much of the energy used; thus, the final costs of desalination can be reduced. Energy recovery using high-pressure systems consist of a system composed of a centrifugal pump, motor and hydraulic turbine that helps the motor to rotate. This system, used from the beginning through the last years, improved over the years until reaching a reduction of one-half of the consumption of the first plants [23]. Subsequently, a remarkable advance was registered: the replacement of the Francis turbines by Pelton turbines, once these were developed as the optimal solution for working with brine.

The latest evolution has occurred with the incorporation of recovery systems that are based on isobaric chambers. These equipment technologies are based on the physical principle of transmission, using the remain brine pressure when feeding seawater into the plant [23]. Energy recovery systems are one of the most important innovations that contribute to the continued growth of desalination: using energy recovery in reverse osmosis plants can contribute $25-30 \%$ to the energy needed to produce potable water. Since 2014 , the typical amount of energy required in the desalination of sea water by reverse osmosis was $3.5 \mathrm{kWh} / \mathrm{m}^{3}$. The use of more efficient membranes has also helped to improve this efficiency [28]. Energy recoveries can help you draw more than $80 \%$ of the energy consumed during the process. The function of these devices is to not waste the pressure used to raise the water, taking advantage of that pressure to transmit energy to the water entering the process, or to trigger an electromagnetic mechanism [16].

However, energy recoveries are not the only front of action to reduce energy consumption. Estevan [18] considers that there are mainly three ways through which energy consumption can be reduced in water desalination plants: first, there is energy recovery by the introduction of isobaric chambers. These energy recovery systems began to appear

in the $90 \mathrm{~s}$, but it has not been until recently that they have gained weight in the desalination industry. This system is based upon the use of the pressurized brine jet to boost the sea water. Through this new method, the brine transmits all of its energy directly to the sea water. With the use of isobaric chambers, the installation's overall performance can reach almost $80 \%$, which means a yield of almost $10 \%$ more than that obtained by the use of Pelton turbines or high-pressure pumps. The second route for reduction of energy that is 
proposed by the author is an improvement in the internal architecture of the plants. In addition to this architectural improvement, it is necessary to improve the plant's elements, in this case the membranes, both in their layout and in their materials. Once the margins of improvement of the hydraulic equipment have been reduced considerably, it is up to the equipment designers to reduce energy consumption, manufacturing membranes that allow working at lower pressure without losing performance, an element that Estevan considers the third way to make improvements. In recent years, membranes that work with pressures around 55-60 atmospheres have been presented on the market as being without loss of performance, when the pressure that is normally used is 70 atmospheres.

A compendium of these improvements can place the consumption of reverse osmosis at the level of $2.5 \mathrm{kWh} / \mathrm{m}^{3}$ and of the whole process, at $3.5 \mathrm{kWh} / \mathrm{m}^{3}$. To reduce such consumption to $2 \mathrm{kWh} / \mathrm{m}^{3}$ and $2.5 \mathrm{kWh} / \mathrm{m}^{3}$ respectively, it would be necessary to combine the use of new low-pressure membranes with the high-performance isobaric chambers, as well as new architecture in both the desalination lines and in the membranes.

\section{THE ECONOMY OF DESALINATION}

The calculus of derivative financial costs of a process of seawater desalination by reverse osmosis can be very complex. In order to understand these costs, we must take into account a number of variables that significantly affect the final cost of the desalinated water: the size of the installation, the physical and geographical conditions of the sea water collection, the product quality required, and the recovery energy system used [20], among others (Table 4).

The complexity of carrying out a study of the costs of desalination is mainly due to the large differences in the desalination plants, such as: the quality of the water to be treated, desalinated water uses, plant size, year of construction, percentage of use, and more. The main costs can be grouped according to the following activities:

- Capture of sea water

- Pretreatment

- Reverse osmosis (most commonly used in Spain)

- Refinement treatment

- Pumping in outside-produced water

- Evacuation of rejection brine

- Treatment of effluents

- Electricity

- Works

Table 4: Cost structure of desalinated water [29].

\begin{tabular}{|l|l|}
\hline \multirow{4}{*}{ Fixed costs } & Amortization \\
\cline { 2 - 2 } & Operational personnel \\
\cline { 2 - 2 } & Power Term \\
\cline { 2 - 2 } & Maintenance and conservation \\
\cline { 2 - 2 } & Administration \\
\cline { 2 - 2 } & Various \\
\hline \multirow{4}{*}{ Variable costs } & Chemical products \\
\cline { 2 - 2 } & Maintenance and conservation \\
\cline { 2 - 2 } & Electric power \\
\cline { 2 - 2 } & Replacement of membranes and cartridges \\
\cline { 2 - 2 } & Equipment renovation \\
\hline
\end{tabular}


In addition, we must not forget other costs, such as personnel and maintenance, which will vary depending on the size of the plant; the chemical additives to be used; or the cost of replacing the membranes or sands of the filters, if they are used.

One of the main costs to take into account is the initial investment required, and that depends mainly on the size of the plant. The specific investment (required investment per $\mathrm{m}^{3} /$ day of production) decreases as the size of the plant increases, which shows that the scale factor plays an important role in the investment. Due to this variation in price, it is difficult to determine whether the economic impact is high or not, depending on the advantages or disadvantages with which they are compared; however, if judged from the perspective of the jobs created, whether for the construction or maintenance of the plant, the ability to have water in spite of drought and more, the impact will be clearly positive.

Following the above, it is clear that economies of scale are very important in obtaining a reduced cost of amortization, if the initial investment is to be recovered. The technological improvements have also been decisive in reducing investment costs. There is great competition between the membrane manufacturers and the contractors. The increase of yield by the pumping equipment is considered as a justification when making a greater initial investment, as well as the improvements in the percentages of recovery and rejection in the membranes [20]. Table 5 shows the representative percentages of each part of the investment and the typical repayment periods for those parts. That is why one of the main causes of underutilization of desalinated water, apart from the fluctuation in demand, is the high price of desalinated water [30].

As mentioned before, the high energy cost of the desalination process is around $48 \%$ of the plant's total production costs [25]. The reform of the electricity market in Spain, carried out in 2008 at the request of the European Union [7], meant an increase in the price of electricity, an increase of around 64\% between 2007 and 2012. It has gone from an average cost in 2007 of $0.9104 € / \mathrm{m}^{3}$ to $1.12 € / \mathrm{m}^{3}$, for all the facilities scheduled in 2012 [25].

As a result, according to the data provided by the company Iberdrola for the year 2014, we can see the example of the 'Mancomunidad de Canales del Taibilla' (one of the main water supply companies on the Mediterranean coast), which placed the energy cost for desalinated water in 2014 at $0.6433 € / \mathrm{m}^{3}$ [30]. The high energy price, coupled with the situation of underutilization of the maximum production capacity, raises the price per cubic meter produced [25]. Another example is observed in the Torrevieja plant. The early 2014 production capacity of this plant was around $20-30 \%$, and the total cost of producing one

Table 5: Percentage of investment and amortization period of the equipment of a seawater desalination plant [20], [29].

\begin{tabular}{|l|c|c|}
\hline & $\begin{array}{c}\text { \% Inversion to the } \\
\text { total }\end{array}$ & $\begin{array}{c}\text { Amortization period } \\
\text { (years) }\end{array}$ \\
\hline Building and urbanization & $8-12$ & 20 \\
\hline Pipelines & $12-16$ & 15 \\
\hline Membranes (includes cleaning) & $25-32$ & 8 \\
\hline Pumping & $15-20$ & 12 \\
\hline Pre-treatment (filters, additives) & $8-10$ & 15 \\
\hline Electric equipment & $9-13$ & 15 \\
\hline Instrumentation and control & $2-4$ & 12 \\
\hline Other (post-treatment, spare parts) & $3-5$ & 15 \\
\hline
\end{tabular}


cubic meter of desalinated water was between 1.2 and $2.8-3.4 €$. These figures are considerably different from those in the initial reports of the A.G.U.A. program, in which it ranged from $0.40-0.60 € / \mathrm{m}^{3}$ [25]. If these prices are compared with those of the TajoSegura transfer, where the $\mathrm{m}^{3}$ is paid at $0.1117 €$, there are prices to pay which can be prohibitive for some users, such as irrigators [31].

Another issue that arises is the economic impact that comes from having the plants stopped or not working at full operational capacity. At this point, we must consider the importance of fixed costs, which will have to be paid, whether the plant functions or not. The Spanish Ministry of the Environment carried out an analysis between 2006 and 2008, which indicated low average costs when the plants worked at full capacity $\left(0.50-0.60 € / \mathrm{m}^{3}\right)$. A new report prepared by the Ministry of Agriculture and Fisheries, Food and Environment (MAGRAMA) in 2012 placed these levels in between $0.85-1.13 € / \mathrm{m}^{3}$, with an increase that was generated by the rise in variable costs, especially energy costs; but even if the plant is not used, it is necessary to continue paying, and if they do not operate at full capacity, then the average costs skyrocket due to the specific weight of the fixed costs (more than $50 \%$ at full operating capacity) [32].

\section{CONCLUSIONS}

Desalination, as a non-conventional method of obtaining potable from brackish water, has been practiced in Spain for decades, especially in the Canary Islands. Given the water imbalances in this country, the need to resort to the practice of desalination was gathering force during its evolution, especially after the consolidation of reverse osmosis as an efficient and effective process. With the change of government, and of water policies, the A.G.U.A. program was promoted in 2004. Through A.G.U.A., a large number of desalination plants were projected, promoting this practice as a solution to the problems of the water deficit in some areas, in order to avoid other types of disputes, such as political or inter-regional disputes, that generated alternative sources of water supply. But the forecasts on the basis of which future water demand was calculated were not met and were well below the estimated numbers. That is why most of the desalination plants built in Spain work at very low capacity and their contribution is not the main, but the complementary, means to ensure the water supply, in case of drought or emergency.

The lack of demand is not the only reason for reduced use of desalinated water. The main problem this practice has is the high energy consumption that it entails, and that has a significant effect on the economic cost of potable water. Desalinated water reaches prices that some users are unable to pay, such as farmers; thus, restricting their use of the supply. Although actions are being taken to reduce this high-energy consumption, such as the use of energy recovery systems or higher-efficiency membranes, energy reduction still remains a problem to be solved.

\section{ACKNOWLEDGEMENTS}

This paper is a result of a pre-doctoral fellowship of the Spanish Researcher Training, in the National Program for Scientific Research, Development and Technological Innovation Research (FPI); and it is inserted into the research project "Use and Management of unconventional water resources on the coast of the regions of Valencia and Murcia, as a strategy for adaptation to drought" (CSO2015-65182-CS-2-P), funded by the Ministry of Economy and Competitiveness. 


\section{REFERENCES}

[1] Swyngedouw, E., Into the sea: Desalination as a Hydro-Social Fix in Spain. Annals of the Association of American Geographers, 103(2), pp. 261-270, 2013.

[2] Botero, E., Valoración energética de los recursos naturales [Energy evaluation of natural resources], Doctoral thesis. University of Zacatecas, México, 2000.

[3] Albaina, A., Tecnologías sostenibles sobre la gestión del agua: La desalación. Estudio del caso en la costa Mediterránea [Sustainable technologies in water resources: Desalination], Final degree project Universidad Politécnica de Cataluña [Polytechnic University of Catalunya], 2007.

[4] Delgado, D.V., Análisis corporativo de los procesos de desalinización del agua: destilación súbita por efecto Flash (MSF) frente a ósmosis inversa (OI), bajo la metodología de evolución del ciclo de vida [Analysis of water desalinization processes: quick distillation by the Flash effect faced with reverse osmosis, in the evolution of cycle-of-life methodology]. Final degree project, Escuela Superior Politécnica del Litoral [Superior Polytechnic School of the Littoral], Guayaquil, Ecuador, 2007.

[5] Al-Ibrahim, A.M., Seawater desalination: the strategic choice for Saudi Arabia, Desalination and water treatment, 51, pp. 1-4, 2013.

[6] Marín, J.J., Desalinización de agua de mar, una opción para el riego de cultivos en zonas áridas [Seawater desalinization, an option for watering crops in arid zones]. Final degree project, Universidad Autónoma Agraria Antonio Narro [Autonomous Agrarian University Antonio Narro], México, 2014.

[7] March, H.; Saurí, D. \& Rico, A.M., The end of scarcity? Water desalination as the new cornucopia for Mediterranean Spain. Journal of Hydrology, 519(C), pp. 26422641, 2014.

[8] Montaño, B., Análisis económico de la desalinización [Economic analysis of desalinization]. Doctoral Thesis, Universidad de Alicante, 2011.

[9] Urrutia, F., Evolución global de la capacidad instaladora de plantas desaladoras [Global evolution of the capacity to install desalinization plants]. Noticias de la AEDYR. Asociación Española de Desalación y Reutilización, 1, pp. 2-5, 2001.

[10] Bates, B.; Kundzwwich, Z.W., Wu, S. \& Palutikof, J., Climate Change and Water. Technical paper of the intergovernmental Panel on Climate Change, Ginebra, 2008.

[11] Bernat, X., Gibert, O., Guiu, R., Tobella, J. \& Campos, C., The economics of desalination for various uses. Re-thinking Water and Food Security: Fourh Botín Foundation Water Workshop, eds. Martínez-Cortina, L., Garrido, A. \& López-Gunn, E., CRC Press/Balkema, Taylor and Francis: Leiden, pp. 329-346, 2010.

[12] Claver, J.M., Trasvase y desalación en la cuenca del Segura [Transport and desalination in the Segura basin], iAgua Magazine, 8, p.78, 2015.

[13] Siddiqi, A. \& Diaz, L., The water-energy nexus in the Middle East and North Africa, Energy Policy, 39, pp. 4529-4540, 2011.

[14] Hardy, L., Garrido, A. \& Juana, L., Evaluation of Spain's Water-Energy Nexus, Water Resources Development, 28(1), pp. 151-170, 2012.

[15] Instituto para la Diversificación y Ahorro de la Energía, IDAE, Estudio de perspectiva. Consumo energético en el sector del agua [Energy consumption by the water sector], Ministerio de Industria, Energía y Turismo [Ministry of Industry, Energy and Tourism], Madrid, 2010.

[16] Arahuetes, A., Desalinización y energía en España. Situación y perspectivas. El caso del Mediterráneo [Desalinization and energy in Spain. Situation and perspectives. 
The case of the Mediterranean]. Gestión de recursos hídricos en España e Iberoamérica. Pamplona: Editorial ARANZADI, ed. Mora, J., p. 529-540, 2015.

[17] Ardiles, L., Desalación en España, iAgua Magazine, 8, p. 76, 2015.

[18] Estevan, A., Desalación, energía y medio ambiente [Desalinization, energy, and the Environment], Panel Científico-Técnico de Seguimiento de la Política de Aguas. Ministerio de Medio Ambiente: Madrid, p. 45, 2008.

[19] Medina, J.A., 20 years evolution of desalination costs in Spain, International Conference on Desalination, Limassol: Chipre, 2004.

[20] Valero, A., Uche, J. \& Serra, L., La desalación como alternativo al PHN [Desalination as an alternative to PHN]. Circe y Universidad de Zaragoza. Presidencia del Gobierno de Aragón, p. 108, 2001.

[21] Torres, M., La desalación de agua de mar. Tecnologías de vanguardia [Desalination of seawater. Vanguard techniques]. Química e industria [Chemistry and Industry], pp. 41-45, 2000.

[22] Estevan, A. \& García, M., El consumo de energía en la desalación de agua de mar por ósmosis inversa: situación actual y perspectivas [Consumption of energy by seawater desalinization via reverse osmosis: current situation and perspectives], Ingeniería Civil, pp. 113-121, 2007.

[23] Torres, M., Avances técnicos en la desalación de aguas [Technical advances in water desalination], Ambienta, pp. 17-26, 2004.

[24] Zarzo, D. \& Rubio, M., Panorama actual de la desalación y de la reutilización para usos agrícolas [Actual desalination panorama and re-utilization by agriculture], Riegos y drenajes XXI, (136), pp. 22-27, 2004.

[25] Del Villar, A., El coste energético de la desalinización en el Programa A.G.U.A. [Energy cost for desalination in the A.G.U.A. program], Investigaciones Geográficas, (62), pp. 101-112. 2014.

[26] García de Durango, A., Agua y sal: la historia de la desalación [Water and salt: the history of desalination], iAgua Magazine, (8), pp. 20-22, 2015.

[27] Iñiguez, A., La situación actual de las desaladoras en el sudeste Mediterráneo, ¿una alternativa a los trasvases? [The desalination plants in the SE Mediterranean: An alternative?], Universidad de Alicante, 2012.

[28] Paulson, L.D., El mundo de la desalinización crece en el mundo a medida que aumenta su eficiencia [The desalinization world grows on earth, as its efficiency grows], 2015, Online. https://www.rwlwater.com/el-uso-de-la-desalinizacion-creceen-el-mundo-a-medida-que-aumenta-su-eficiencia/?lang=es.

[29] Fariñas, M., El coste del agua producida por las grandes desaladoras de agua de mar en España [The cost of water produced by the large seawater desalinization plants in Spain], Ingeniería y territorio, (72), pp. 62-67, 2005.

[30] Arahuetes, A., Villar, R. \& Hernández, M., El ciclo hidrosocial en la ciudad de Torrevieja: retos y nuevas tendencias [The hydrosocial cycle in Torrevieja city: challenges and new tendencies], Revistas de Geografia Norte Grande, (65), pp. 109128, 2016.

[31] Rico, A.M., Plan Hidrológico Nacional y Programa A.G.U.A.: Repercusiones en las regiones de Murcia y Valencia [National hydrological plan and the A.G.U.A. program: repercussions in the regions of Murcia and Valencia], Investigaciones Geográficas, (51), pp. 235-267, 2010.

[32] Maestu, J. \& Del Villar, A., Los costes de la desalación, ¿ahorramos no produciendo? [The costs of desalination: do we save by not producing?], iAgua Magazine, (8), p. 77, 2015. 